\title{
Evaluating Innovations from a Critical Thinking Approach
}

\section{Dr. Sarah Jane Grigg, Clemson University}

Dr. Sarah Grigg is a senior lecturer in General Engineering at Clemson University. She is a human factors design engineer specializing in process improvement and error mitigation across various contexts including engineering education, healthcare, and transportation. She received Ph.D., M.S. and B.S. degrees in Industrial Engineering, a Certificate in Engineering Education, and a Masters degree in Business Administration from Clemson University. 


\section{Evaluating Innovations from a Critical Thinking Approach}

One strategic initiative at Clemson University is to promote innovation and entrepreneurship among faculty and students. One of the channels for introducing students to innovation and entrepreneurship at Clemson University is a course offered through the General Engineering program, ENGR 2200: Evaluating Innovations: Fixtures, Fads, and Flops. This general education course was designed to actively engage students in deep thinking about the relationships between innovation and society. The goals of this class are two-fold: 1) students gain an understanding of how societal and technological trends drive innovation, and 2) students learn and apply critical thinking techniques to critically analyze the impact of innovations on society and identify opportunities for innovation. The course content introduces engineering students to foundational theories of innovation, product development, and consumer behavior which are used to analyze the success of consumer products and other technological innovations.

A SCALE-UP (Student-Centered Activities for Large-Enrollment Undergraduate Programs) environment is utilized in this course. SCALE-UP is a highly collaborative, hands-on classroom format where the primary emphasis is on learning by guided inquiry rather than by traditional lecturing. Student engagement is fostered using this approach as students are able to work together in small groups to uncover their own thought and biases before discussing difficult or controversial topics surrounding engineering innovation with the class as a whole. While the course is taught specifically with engineering design in mind, the course has attracted students from varying majors which has fostered collaboration and creativity in idea generation. The combination of critical thinking methodology with innovation concepts has led students to not only expand their knowledge of potential applications of engineering, but has lead several students to initiate communication with faculty members regarding their ideas for research opportunities, innovation competitions, and initiated their own projects via applying for University Innovation Fellows program.

\section{Background}

Innovation and entrepreneurship have been part of the engineering curriculum for several decades [1]. However, students many not encounter these subjects through their required engineering courses until their junior or senior year, typically during a capstone design course. While opportunities exist for students to learn about innovation and entrepreneurship through elective courses, these options are not typically available to first-year students or do not fulfill a requirement for their academic plan.

First-year courses are the cornerstone experiences that expose students to foundational concepts and foster the development of skills necessary for students to succeed in their field of study and ultimately their career. For disruptive innovators, those behavioral skills include: questioning, observing, networking, and experimenting $\mathrm{s}$ [2]. Critical thinking is then used to form associations between content, effectively linking ideas/processes/solutions together which helps innovators generate new uses for existing technologies modification to existing technologies that can improve the effectiveness [3]. 
One of the recent strategic initiatives of [our] University is promoting innovation and entrepreneurship, specifically within the engineering majors. Evaluating Innovation: Fixtures, Fads, and Flops was developed to create a cornerstone experience that infuse innovation and entrepreneurship into the first-year in an intentional way, integrated as a new course offering to fulfill an existing general education requirement. The course engages students in deep thinking about the relationships between innovation and society and consequences of design flaws. The focus of this class is on the reciprocating nature of the interactions between innovation and society. The examination of this relationship lends itself naturally to the use of critical thinking and is used as a tool for evaluation throughout the course. At the end of the course, students should be able to 1) demonstrate an understanding of issues created by the complex interactions among science, technology, and society, and 2) demonstrate the ability to assemble information relevant to a significant, complex issue, evaluate the quality and utility of the information, and use the outcome of the analysis to reach a logical conclusion about the issue.

\section{Course Content and Theoretical Models}

The course introduces students to foundational theories of innovation and evaluation methods to engage students in thinking critically about product development from a broad range of perspectives. Specifically, students learn to evaluate innovations from technological, business, human, and environmental perspectives. Figure 1 shows a breakdown of course content. Students are introduced to foundational theories for promoting innovation through company culture [4], individual mindset [5], and design thinking methodology [6]. Additionally, students are exposed to various tools to evaluate innovation from financial [7], social [8], and environmental perspectives [9] as well as a critical thinking approach [3] to analyze an issue to thoroughly and to high quality standards.

\begin{tabular}{|c|c|c|}
\hline \multicolumn{3}{|c|}{ Course Content } \\
\hline $\begin{array}{l}\text { Distribution of content coverage in this class include: } \\
\text { - Critical Thinking - } 20 \% \\
\circ \quad \text { Elements of reasoning } \\
\circ \quad \text { Intellectual standards } \\
\circ \quad \text { Heuristics and decision making } \\
\text { - Innovation Mindset - } 20 \% \\
\circ \quad \text { Human-centered design thinking } \\
\circ \quad \text { Product development process } \\
\circ \quad \text { Innovation (change) style } \\
\text { - Evaluating Innovation Success - 20\% } \\
\circ \quad \text { Product Life Cycle } \\
\circ \quad \text { Market/Situation Analysis } \\
\circ \quad \text { Technology Adoption / Diffusion of innovation }\end{array}$ & $\begin{array}{l}\text { - So } \\
\text { - } \quad \operatorname{Pr} \\
0 \\
0 \\
\text { Co } \\
0 \\
\circ \\
\circ\end{array}$ & $\begin{array}{l}\text { ietal Factors and Implications- 20\% } \\
\text { Disruptive Innovations } \\
\text { Hierarchy of human needs } \\
\text { Environmental impact } \\
\text { fessional Communication - } 10 \% \\
\text { Critical analysis of innovation and innovative } \\
\text { technologies (written and presented) } \\
\text { Objectively engage in group discussions } \\
\text { arse Mechanics and Assessment - 10\% } \\
\text { California Critical Thinking Tests (2) } \\
\text { Module Quizzes (10) } \\
\text { Exams (3) }\end{array}$ \\
\hline
\end{tabular}

Figure 1: Overview of content delivered in Evaluating Innovation: Fixtures, Fads, and Flops

\section{Course Development and Timeline of Interventions}

2014-2015- The development of [this course] began in February 2014 when it was proposed as a new course development for a Critical Thinking Faculty Institute encouraging instructors to offer courses that "focused on developing students' ability to think critically and to communicate 
effectively." [10] This course was piloted in Spring 2015 as a seminar course for 20 students. Classes were largely class discussions with students driving conversation with topics and experiences relevant to their lives. While this style was effective in developing critical thinking and communication skills, students felt it conflicted with their expectations of an engineering course and requested more hands-on activities.

2015-2016 - In Fall 2015, the course was introduced on a larger scale using SCALE-UP methods for 3 sections of 40 students. SCALE-UP (Student-Centered Activities for Large-Enrollment Undergraduate Programs) is a highly collaborative, hands-on classroom format where the primary emphasis is on learning by guided inquiry rather than by traditional lecturing [11, 12, 13, 14]. Student engagement is fostered using this approach as students are able to work together in small groups to uncover their own thought and biases before discussing difficult or controversial topics surrounding engineering innovation with the class as a whole. Figures 2-4 show some of these activities. Figure 2 shows a design thinking exercise that illustrates the difference in working harder and working smarter. Students are instructed to design a way to get an object from point $\mathrm{A}$ to point $\mathrm{B}$ where there is a barrier between. Most start by building a bridge or catapult while going around is a simply feasible alternative. As seen in Figure 3, when discussing the differences between incremental, breakthrough, and disruptive innovations, lighting is used as an example to highlight these differences. To expand on the topic, students build an electrical circuit to compare the brightness and voltage drops across incandescent and led bulbs. Figure 4 shows an ideation session to address a grand challenge [15] where students use random objects to simulate a design. This requires students to use diverse thinking and image possibilities beyond traditional uses of existing products. The idea shown simulated a way to remove water impurities using an enclosure with a weight sensor that releases the cover allowing impurities to be lifted out when enough of them had been captured in the containment area. Obviously this idea would need some more intensive work to become a feasible solution, but the creativity is evident and certainly students come out with a stronger awareness for these important engineering problems that are in need of innovative solutions.
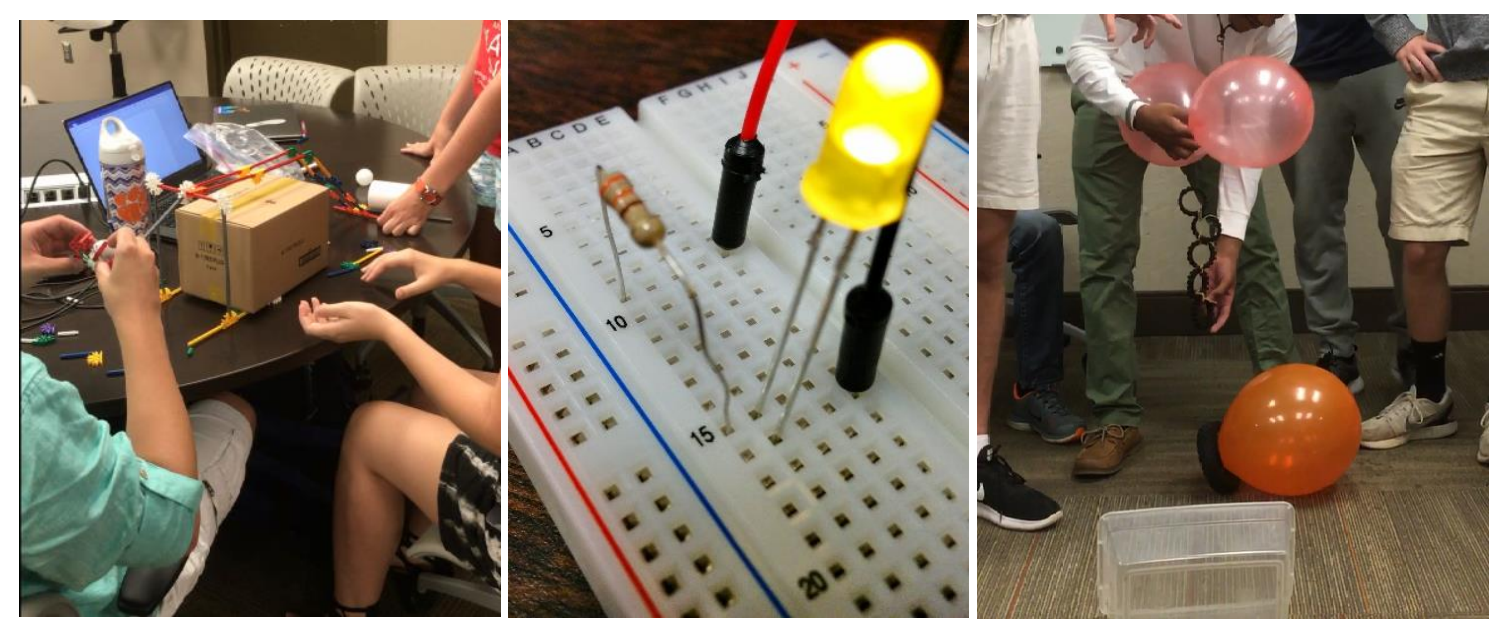

Figures 2-4: In-class activities allow students to expand their learning by exercising creative and critical thinking skills in small groups. 
2016-2017 - In response to student feedback, two modifications were made to the course: 1) an immersive approach used to introduce critical thinking as a framework within a module on engineering design failures and accident investigation rather than as its own module on critical thinking theory and 2) the use of peer evaluations was eliminated. This stronger connection to application of the theory in the engineering profession improved student engagement with the module. In this module students are shown how the critical thinking framework [3] is used to uncover the sources of the failures and use that knowledge to prevent repeating the same mistake. Next students are led through a discussion of heuristics and errors from cognitive biases. They then self-reflect on their own failures in judgement and self-assess factors that influence their behavior. While students seemed to engage with the content more on commented favorably about the content in this module being exciting and relevant, the reduction in emphasis of critical thinking theory coupled with the reduced emphasis on the practice of evolution peers analyses likely reduced the potential learning gains in critical thinking.

2017-2018 - This year brought two more modifications: 1) Digital Storytelling was introduced to improve communication of innovative ideas and 2) the (PREP)ARE modular structure [16] was introduced into the online course management software. The digital storytelling project had students evaluate a grand challenge and ideate potential solutions. They utilize Adobe Spark s to capture an artifact documenting the result of their design thinking process to address the grand challenge of their choice. Figure 5 shows a sample submission. Students express their ideas based on theories from class such as a SWOT analysis and low fidelity prototypes.

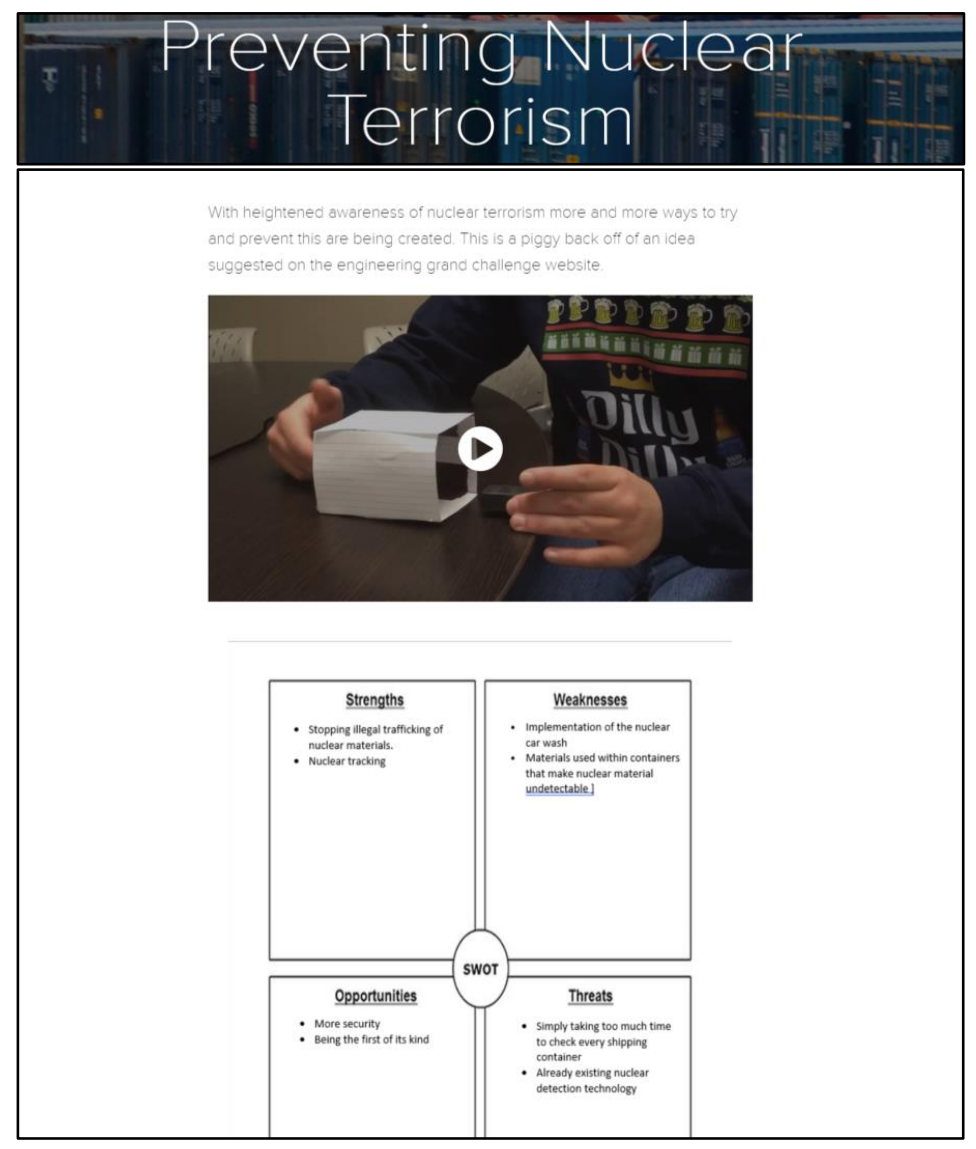

Figure 5: Sample of student work documenting innovation using Adobe Spark 
The (PREP)ARE modular structure was introduced following positive results in two foundational courses taught by the GE Program. Figure 6 shows the first page of a (PREP) module presented to students for the module on critical thinking in engineering design.

The weekly modules offer a repeated cycle of activities with standardized assessment rubrics. This structure helps guide students through an active learning experience of reflection (Preview), knowledge discovery (Read), hands-on activities and simulations (Exercise), and peer-lead discussions (Ponders). Incorporating the acronym into course assignment names has improved the students' awareness of deadlines and expectations for each class period. Figure 7 shows the assignment submission fields as students interact with them in CANVAS.

Each module consists of four elements:

1) Preview (discussion post): In this reflective activity, students document their current understanding or beliefs on a topic relevant to the lecture through a discussion board post. Assessments are completed with a Learning GAIN Likert scale for two criteria; completion and quality. This gives a way of providing partial credit based on performance, though it is likely to be nearly as effective to grade Preview activities on a Complete/Incomplete with lower grading demand as this still encourages the documentation that leads to deep learning regarding the topic.

2) Read (timed quiz): In this activity students get a low stakes chance of reviewing important concepts and ensure their understanding of the foundational topics before they get to the exam. Each quiz consists of 5 auto-graded questions based on the reading. Questions are mostly multiple choice or matching and students receive immediate feedback from the course management system to assess their reading comprehension.

3) Expand learning (and Exercise Thinking skills): Each live course devotes a class period each week to a hands-on activity allowing students to exercise their creative and critical thinking skills. Both online and live course offerings focus on exercising critical thinking skills by researching a topic and writing a brief essay describing their critical analysis of an innovation based on the critical thinking elements.

4) Ponder (group discussion): During one class period of the week, students engage in a Think-Pair-Share activity, discussing historical innovations that were disruptive to the culture of the American population, shaping the world as we know it today. Students are broken up into groups of 7, each selecting one of the seven related innovations for a particular industry. Each student becomes "the expert" on their selected innovation and presents a summary of implications of the innovation to the group. Then as class we review the key trends and insights. Individual summaries were assessed with a checklist of items that were consistently used as prompts for each module's Ponder assignment. 


\section{Overview of Critical Thinking in Engineering Design}

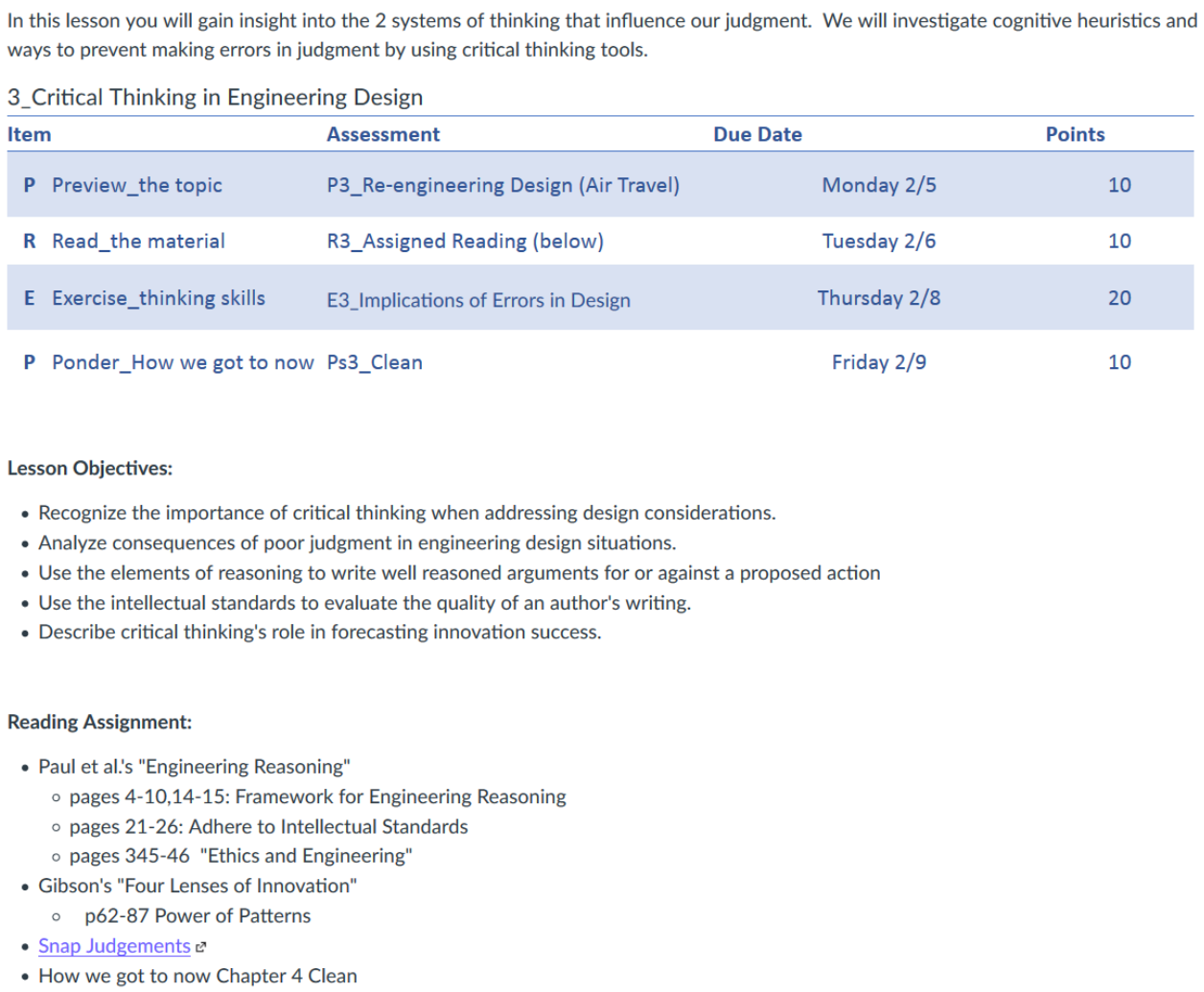

Figure 6: Example layout of a module overview page with assignment names coded to match the PREP cycle stage for a general education course on innovation.

\begin{tabular}{|c|c|c|c|c|}
\hline \multicolumn{2}{|c|}{ :: 3 Critical Thinking in Engineering Design } & Complete All Items $Q$ & + & $\vdots$ \\
\hline : 国 O & verview of Critical Thinking in Engineering Design & & $\bullet$ & $\vdots$ \\
\hline$\because: \& \mathrm{Cr}$ & itical Thinking: Elements of Thought and Intellectual standards & & $\bullet$ & $\vdots$ \\
\hline : 专 Vic & deo Lecture_Critical Thinking in Engineering Design & & $\bullet$ & $\vdots$ \\
\hline :苂 $\mathrm{Pa}$ & rtial list of cognitive heuristics used in decision making. & & $\bullet$ & $\vdots$ \\
\hline : 國 & $\begin{array}{l}\text { P3_Engineering Design Failures and Innovation (Aerospace Case Studies) } \\
\text { Feb } 5 \text { | } 10 \text { pts | View }\end{array}$ & & $\bullet$ & $\vdots$ \\
\hline : 8 & $\begin{array}{l}\text { R3_Critical Thinking in Engineering Design } \\
\text { Feb } 6 \text { | } 10 \text { pts | View }\end{array}$ & & $\bullet$ & $\vdots$ \\
\hline :ः區 & $\begin{array}{l}\text { E3_Implications of Errors in Engineering Design } \\
\text { Feb } 8 \text { | } 20 \text { pts | View }\end{array}$ & & $\bullet$ & $\vdots$ \\
\hline : 印 & $\begin{array}{l}\text { Ps3_Disruptive Innovations in "Clean" } \\
\text { Feb } 9 \text { | } 10 \text { pts | View }\end{array}$ & & $\bullet$ & $\vdots$ \\
\hline
\end{tabular}

Figure 7: The assignments mimic the acronym PREP to guide students through the module with progressive assignments that follow the pattern set forth by the model. 


\section{Assessment of Learning Objectives}

The objectives of this course are for students to gain an understanding of how societal factors and innovation influence each other and improve critical thinking, and communication skills. Learning objectives are assessed using the course comprehensive final exam, though progress is also evaluated throughout each module with small stakes assignments, worth 10-20 points compared to the 150 points of an exam. While the assessment have a small impact on final course grades, they provide students the opportunity to learn from their mistakes by reviewing feedback from the grading rubrics. Example rubrics used to evaluate critical thinking exercises for are included in Appendices A and B. Appendix C shows the latest version of the rubric that is currently in use.

Students regularly achieve course performance scores within the target $80-85 \%$ accuracy for all objectives of the course. While this measure is important, it is also easy to erroneously make conclusions based only on internal assessment measures. Therefore, critical thinking skills are regularly assessed using an external evaluation measure, the California Critical Thinking Skills Test (CCTST). Pre and post evaluations were conducted and serve as an external evaluation of learning gains. A summary of results is shown in Table 1. In general, gains of about 10 percentile were experienced on average, with a smaller gain seen in Fall 2016. Based on these results, peer evaluations will be reincorporated into the course as well as re-revising the module on critical thinking in engineering design to spend more time actively working through the critical thinking elements when analyzing case studies.

Table 1: Summary of Critical Thinking Learning Gains over the term for each course offering

\begin{tabular}{|l|c|c|c|c|c|}
\hline Semester & Group & Class size & $\begin{array}{l}\text { Pre-Test } \\
\text { Average } \\
\text { Percentile }\end{array}$ & $\begin{array}{l}\text { Post-Test } \\
\text { Average } \\
\text { Percentile }\end{array}$ & $\begin{array}{l}\text { Critical Thinking } \\
\text { GAIN } \\
\text { (mean change in } \\
\text { percentile) }\end{array}$ \\
\hline Spring 2015 & General & 20 & 70 & 80 & 10 \\
\hline \multirow{3}{*}{ Fall 2015 } & General & 37 & 63 & 75 & 12 \\
\cline { 2 - 6 } & General & 39 & 59 & 65 & 6 \\
\cline { 2 - 6 } & RiSE & 39 & 65 & 77 & 12 \\
\hline Spring 2016 & General & 18 & 72 & 83 & 11 \\
\hline Summer 2016 & Online & 7 & 58 & 68 & 10 \\
\hline Fall 2016 & RiSE & 38 & 71 & 72 & 1 \\
\hline Summer 2017 & Online & 9 & 70 & 79 & 9 \\
\hline
\end{tabular}

\section{Conclusions}

While the course is taught specifically with engineering design in mind, the course has attracted students from varying majors which has fostered collaboration and creativity in idea generation. So far this course has succeeded in exposing 284 students to innovation and entrepreneurship topics and provided opportunities for the development of critical thinking and communication 
skills through the analysis of relationship between science, technology, and society. The combination of critical thinking methodology with innovation concepts has led students to not only expand their knowledge of potential applications of engineering, but has prompted several students to pursue entrepreneurial interest such as approaching faculty members regarding their ideas for input, competing in innovation competitions, and initiating their own makers projects via applying for funding or participating in other entrepreneurial programs such campus programs such as the Design \& Entrepreneurship Network (DEN) and nation programs like University Innovation Fellows (UIF). While the course is still under refinement, it is a promising addition to the curriculum and has the potential to inspire young innovators to solve the global engineering challenges.

\section{Future Research}

Design (even instructional) is an iterative cycle of assessment and refinement. It is very easy for interventions with good intentions to have unforeseen negative consequences. Here, focusing on incorporating activities to encourage the development of creativity and risk taking to form an innovative mindset seems to have overpowered the focus on developing critical thinking skills. Both are important, and finding the correct balance will be the focus of future work. The

Additionally, a comparison of performance of students from different residential groups will be investigated. In the 2017-2018 academic year, the course will be delivered to four different groups of students: 1) Online, 2) General Engineering Learning Community (GELC), 3) Residents in Science and Engineering Living Learning Community (RiSE), and 4) General population open to all majors. Ongoing research will investigate variations in performance across these populations to determine whether this course is appropriate for the first year engineering student, despite being designed as a sophomore level critical thinking course and whether a prerequisite of English composition is needed to ensure the adequate preparation for the deep thinking and communication skills used in this course.

\section{Works Cited}

[1] W. P and B. T, "Entrepreneurship and innovation in engineering education," Advances in Engineering Education, vol. 5, no. 1, 2016.

[2] J. Dyer, H. Gregersen and C. Christensen, "The Innovator's DNA: MAstering the Five Skills of Disruptive Innovators," Harvard Business Review, 2011.

[3] R. Paul, R. Niewoehner and L. Elder, The Thinker's Guide to Engineering Reasoning, tomales, CaliFornia: Foundation For Critical Thiking Press, 2013.

[4] J. Byrd, "Perspe," in The Innovation Equation: Building Creativity and Risk-Taking in Your Organization, Wiley, 2002, p. 224.

[5] R. Gibson, The 4 lenses of Innovation: A power tool for creative thinking, Hoboken, New Jersey: Wiley, 2015.

[6] Stanford d.school, "A Virtual Crash Course in Design Thinking," Hasso Plattner Institute of Design, 2017. [Online]. Available: https://dschool.stanford.edu/resources-collections/avirtual-crash-course-in-design-thinking. 
[7] J. Riley, "Product Life Cycle," 2015. [Online]. Available: https://www.tutor2u.net/business/reference/product-life-cycle.

[8] G. Moore, Crossing the Chasm: Marketing and Selling High-Tech Products to Mainstream Customers, Harper Collins, 2014.

[9] thinkstep, "What is the Life Cycle Assessment (LCA) Methodology?," 2018. [Online]. Available: https://www.thinkstep.com/life-cycle-assessment-lca-methodology.

[10] "Clemson Thinks2," April 2013. [Online]. Available: https://www.clemson.edu/academics/programs/thinks2/documents/QEP-report.pdf.

[11] M. Prince and R. Felder, "Inductive teaching and learning methods: Definitions, comparisons, and research bases," Journal od Engineering Education, vol. 95, no. 2, pp. 123-138, 2006.

[12] L. Benson, M. Orr, S. Biggers, W. Moss and S. Schiff, "Student-Centered Active Cooperative Learning in Engineering," International Journal of Engineering Education, vol. 26, no. 5, pp. 1097-1110, 2010.

[13] R. Beichner, J. Saul and D. Abbot, "Student Centered Activities for Large Wnrollment Undergraduate Programs (SCALE-UP) project," in Research Based Reform of University Physics, College Park, MD, American Association of Physics Teachers.

[14] H. Oliver-Hoyo and R. Beichner, "SCALE-UP: Bringing Inquiry-Guided Methods to Large Enrollment Courses," in Teaching and Learning Through Inquiry: A Guidebook for Institutions and Instructors, Sterling, Va, Stylus, 2004.

[15] National Academy of Engineering, "NAE Grand Challenges for Engineering," 2018. [Online]. Available: http://engineeringchallenges.org/.

[16] S. Grigg and E. Stephen, "(PREP)ARE: A student centered approach to provide scaffolding in a flipped classroom environment," in ASEE Annual Conference and Expo, Salt Lake City, Utah, 2018. 


\section{APPENDIX A: Spring 2015, Fall 2016, Spring 2016}

\section{Critical Thinking Rubric based on elements of thought and intellectual standards}

\begin{tabular}{|c|c|c|c|c|c|c|c|c|}
\hline & & & & $\begin{array}{c}\text { Missing } \\
0\end{array}$ & $\begin{array}{c}\text { Needs Improvement } \\
1\end{array}$ & $\begin{array}{l}\text { Adequate } \\
2\end{array}$ & $\begin{array}{c}\text { Good } \\
3\end{array}$ & $\begin{array}{l}\text { Excellent } \\
\quad 4\end{array}$ \\
\hline \multirow{9}{*}{ 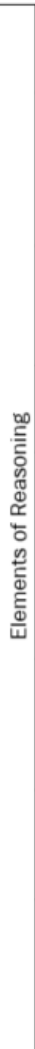 } & Purpose & 4 & 4 & $\begin{array}{l}\text { Not } \\
\text { identifiable } \\
\text { in essay }\end{array}$ & $\begin{array}{l}\text { Explains the purpose of the } \\
\text { paper in the conclusion } \\
\text { only }\end{array}$ & $\begin{array}{l}\text { The purpose of the paper is } \\
\text { not directly stated in the } \\
\text { introduction but can be } \\
\text { inferred from information }\end{array}$ & $\begin{array}{l}\text { Explains the purpose of the } \\
\text { paper in the introduction }\end{array}$ & $\begin{array}{l}\text { Explains the purpose of the paper in } \\
\text { the introduction, which is } \\
\text { distinguished from related purposes } \\
\text { and is realistic and achievable }\end{array}$ \\
\hline & $\begin{array}{l}\text { Questions } \\
\text { (Engineering } \\
\text { Problem) }\end{array}$ & 4 & 4 & $\begin{array}{l}\text { Not } \\
\text { identifiable } \\
\text { in essay }\end{array}$ & $\begin{array}{l}\text { Mentions a problem being } \\
\text { addressed by the } \\
\text { object/idea/innovation but } \\
\text { does not describe it }\end{array}$ & $\begin{array}{l}\text { Briefly describes a problem } \\
\text { being addressed by the } \\
\text { object/idea/innovation/regul } \\
\text { ation under investigation but } \\
\text { does not describe the context } \\
\text { / environment }\end{array}$ & $\begin{array}{l}\text { Describes a problem being } \\
\text { addressed by the object// } \\
\text { idea/innovation/regulation } \\
\text { under investigation and } \\
\text { mentions the context/ } \\
\text { environment but does not } \\
\text { connect the two }\end{array}$ & $\begin{array}{l}\text { Describes a problem being } \\
\text { addressed by the } \\
\text { object//idea/innovation/regulation } \\
\text { under investigation in relation to the } \\
\text { context / environment and } \\
\text { describes how the two are } \\
\text { connected }\end{array}$ \\
\hline & Data/ & 4 & 4 & $\begin{array}{l}\text { Not } \\
\text { identifiable } \\
\text { in essay }\end{array}$ & $\begin{array}{l}\text { Information is taken from } \\
\text { source(s) that are not } \\
\text { reviewed / reputable }\end{array}$ & $\begin{array}{l}\text { Information is taken from } \\
\text { source(s) that are not } \\
\text { reviewed / reputable }\end{array}$ & $\begin{array}{l}\text { Information is taken from } \\
\text { reputable source(s). }\end{array}$ & $\begin{array}{l}\text { Information is taken from reputable } \\
\text { source(s). }\end{array}$ \\
\hline & nation & & & & $\begin{array}{l}\text { Viewpoints of experts are } \\
\text { taken as fact }\end{array}$ & $\begin{array}{l}\text { Viewpoints of experts are } \\
\text { taken as mostly fact }\end{array}$ & $\begin{array}{l}\text { Viewpoints of experts are } \\
\text { subject to questioning. }\end{array}$ & $\begin{array}{l}\text { Viewpoints of experts are } \\
\text { questioned thoroughly. }\end{array}$ \\
\hline & $\begin{array}{l}\text { Key } \\
\text { Concepts } \\
\text { (Theories) } \\
\end{array}$ & 4 & 4 & $\begin{array}{l}\text { Not } \\
\text { identifiable } \\
\text { in essay }\end{array}$ & $\begin{array}{l}\text { Mention one theory from } \\
\text { class but does not clearly } \\
\text { incorporate it into the } \\
\text { analysis }\end{array}$ & $\begin{array}{l}\text { Mention one or more theory(s) } \\
\text { from class but connection to } \\
\text { the analysis is weak }\end{array}$ & $\begin{array}{l}\text { Explain relevant theory(s) } \\
\text { from class and incorporates it } \\
\text { into the analysis }\end{array}$ & $\begin{array}{l}\text { Explain relevant theory(s) from class } \\
\text { and incorporates it into the } \\
\text { analysis, using the theory to explain } \\
\text { or question judgment }\end{array}$ \\
\hline & $\begin{array}{l}\text { Points of } \\
\text { View }\end{array}$ & 4 & 4 & $\begin{array}{l}\text { Not } \\
\text { identifiable } \\
\text { in essay }\end{array}$ & $\begin{array}{l}\text { Specific position } \\
\text { (perspective, } \\
\text { thesis/hypothesis) is } \\
\text { stated, but is simplistic and } \\
\text { obvious. }\end{array}$ & $\begin{array}{l}\text { Specific position (perspective, } \\
\text { thesis/hypothesis) } \\
\text { acknowledges different sides } \\
\text { of an issue but does not } \\
\text { evaluate them in depth. }\end{array}$ & $\begin{array}{l}\text { Specific position (perspective, } \\
\text { thesis / hypothesis) discusses } \\
\text { complexities of issues. } \\
\text { Limitations of position } \\
\text { (perspective, } \\
\text { thesis/hypothesis) are } \\
\text { acknowledged. }\end{array}$ & $\begin{array}{l}\text { Specific position (perspective, } \\
\text { thesis / hypothesis) is imaginative, } \\
\text { discusses complexities of issues } \\
\text { Limitations of position/perspective, } \\
\text { thesis / hypothesis are } \\
\text { acknowledged. } \\
\text { Others' points of view are } \\
\text { acknowledged within position } \\
\text { (perspective, thesis / hypothesis). }\end{array}$ \\
\hline & Assumptions & 4 & 4 & $\begin{array}{l}\text { Not } \\
\text { identifiable } \\
\text { in essay }\end{array}$ & $\begin{array}{l}\text { Shows an emerging } \\
\text { awareness of present } \\
\text { assumptions (sometimes } \\
\text { labels assertions as } \\
\text { assumptions). }\end{array}$ & $\begin{array}{l}\text { Questions some assumptions. } \\
\text { Identifies several relevant } \\
\text { contexts when presenting a } \\
\text { position. May be more aware } \\
\text { of others' assumptions than } \\
\text { own (or vice versa). }\end{array}$ & $\begin{array}{l}\text { Identifies own and others' } \\
\text { assumptions and several } \\
\text { relevant contexts when } \\
\text { presenting a position. }\end{array}$ & $\begin{array}{l}\text { Thoroughly (systematically and } \\
\text { methodically) analyzes own and } \\
\text { others' assumptions and carefully } \\
\text { evaluates the relevance of contexts } \\
\text { when presenting a position. }\end{array}$ \\
\hline & Inferences & 4 & 4 & $\begin{array}{l}\text { Not } \\
\text { identifiable } \\
\text { in essay }\end{array}$ & $\begin{array}{l}\text { Information is taken from } \\
\text { source(s) without any } \\
\text { interpretation or evaluation. }\end{array}$ & $\begin{array}{l}\text { Information is taken from } \\
\text { source(s) with some } \\
\text { interpretation /evaluation, but } \\
\text { not enough to develop a } \\
\text { coherent analysis. }\end{array}$ & $\begin{array}{l}\text { Information is taken from } \\
\text { source(s) with enough } \\
\text { interpretation/evaluation to } \\
\text { develop a coherent analysis. }\end{array}$ & $\begin{array}{l}\text { Information is taken from source(s) } \\
\text { with enough } \\
\text { interpretation/evaluation to develop } \\
\text { a comprehensive analysis. }\end{array}$ \\
\hline & Implications & 4 & 4 & $\begin{array}{l}\text { Not } \\
\text { identifiable } \\
\text { in essay }\end{array}$ & $\begin{array}{l}\text { Conclusion is inconsistently } \\
\text { tied to some of the } \\
\text { information discussed; } \\
\text { related outcomes } \\
\text { (consequences and } \\
\text { implications) are } \\
\text { oversimplified. }\end{array}$ & $\begin{array}{l}\text { Conclusion is logically tied to } \\
\text { information (because } \\
\text { information is chosen to fit } \\
\text { the desired conclusion); some } \\
\text { related outcomes } \\
\text { (consequences and } \\
\text { implications) are identified. }\end{array}$ & $\begin{array}{l}\text { Conclusion is logically tied to } \\
\text { a range of information, } \\
\text { including opposing } \\
\text { viewpoints; related outcomes } \\
\text { (consequences and } \\
\text { implications) are identified } \\
\text { clearly. }\end{array}$ & $\begin{array}{l}\text { Conclusions and related outcomes } \\
\text { (consequences and implications) } \\
\text { are logical and reflect student's } \\
\text { informed evaluation and ability to } \\
\text { place evidence and perspectives } \\
\text { discussed in priority order. }\end{array}$ \\
\hline
\end{tabular}

\begin{tabular}{|c|c|c|c|c|c|c|c|c|}
\hline & & & & $\begin{array}{c}\text { Missing } \\
0\end{array}$ & $\begin{array}{c}\text { Needs Improvement } \\
1\end{array}$ & $\begin{array}{l}\text { Adequate } \\
2\end{array}$ & $\begin{array}{c}\text { Good } \\
3\end{array}$ & $\begin{array}{c}\text { Excellent } \\
\quad 4\end{array}$ \\
\hline \multirow{8}{*}{ 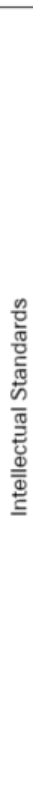 } & Clarity & 4 & 4 & $\begin{array}{l}\text { Not } \\
\text { identifiable in } \\
\text { essay }\end{array}$ & $\begin{array}{l}\text { Reasoning is unclear, } \\
\text { illogical, and leaves the } \\
\text { reader confused }\end{array}$ & Reasoning is vague. & $\begin{array}{l}\text { Reasoning seems sound, but } \\
\text { could use more elaboration } \\
\text { and details }\end{array}$ & $\begin{array}{l}\text { Reasoning is clear, } \\
\text { presented well, enough } \\
\text { elaboration and details or } \\
\text { examples }\end{array}$ \\
\hline & Accuracy & 4 & 4 & $\begin{array}{l}\text { Not } \\
\text { identifiable in } \\
\text { essay }\end{array}$ & $\begin{array}{l}\text { Reasoning is flawed and } \\
\text { lacks reliable sources }\end{array}$ & $\begin{array}{l}\text { Reasoning is accurate } \\
\text { though does not add } \\
\text { anything beyond } \\
\text { information learned in } \\
\text { class, and lacks reliable } \\
\text { sources, uses hearsay as } \\
\text { fact }\end{array}$ & $\begin{array}{l}\text { Reasoning is accurate though } \\
\text { does not add anything beyond } \\
\text { information learned in class, } \\
\text { and used reliable sources }\end{array}$ & $\begin{array}{l}\text { Reasoning is accurate, in } \\
\text { accordance with engineering } \\
\text { theory, and used reliable } \\
\text { sources }\end{array}$ \\
\hline & Precision & 4 & 4 & $\begin{array}{l}\text { Not } \\
\text { identifiable in } \\
\text { essay }\end{array}$ & $\begin{array}{l}\text { Flounders across a range } \\
\text { of topics or ideas that are } \\
\text { not connected }\end{array}$ & $\begin{array}{l}\text { Flounders across topics, } \\
\text { but also includes specific } \\
\text { details }\end{array}$ & $\begin{array}{l}\text { Specific but could use more } \\
\text { details or at a level that is } \\
\text { inappropriate for the } \\
\text { audience }\end{array}$ & $\begin{array}{l}\text { Specific and with enough } \\
\text { details, appropriate for the } \\
\text { audience }\end{array}$ \\
\hline & Relevance & 4 & 4 & $\begin{array}{l}\text { Not } \\
\text { identifiable in } \\
\text { essay }\end{array}$ & $\begin{array}{l}\text { Reasoning is irrelevant to } \\
\text { the purpose of the paper }\end{array}$ & $\begin{array}{l}\text { Reasoning is partially in line } \\
\text { with the purpose of the } \\
\text { essay but includes some } \\
\text { irrelevant topics }\end{array}$ & $\begin{array}{l}\text { Reasoning was in line with the } \\
\text { purpose of the essay. Author } \\
\text { refrains from discussing } \\
\text { irrelevant topics }\end{array}$ & $\begin{array}{l}\text { Reasoning was focused, } \\
\text { direct, and in line with the } \\
\text { purpose of the essay. Autho } \\
\text { refrains from discussing } \\
\text { irrelevant topics }\end{array}$ \\
\hline & Depth & 3 & 4 & $\begin{array}{l}\text { Not } \\
\text { identifiable in } \\
\text { essay }\end{array}$ & $\begin{array}{l}\text { Did not include details } \\
\text { about the topics }\end{array}$ & $\begin{array}{l}\text { Incorporated detail about } \\
\text { the topic under } \\
\text { investigation but was vague }\end{array}$ & $\begin{array}{l}\text { Incorporated detail about the } \\
\text { topic under investigation but } \\
\text { was wav too much }\end{array}$ & $\begin{array}{l}\text { Incorporated enough detail } \\
\text { about the topic under } \\
\text { investigation as appropriate }\end{array}$ \\
\hline & Breadth & 3 & 4 & $\begin{array}{l}\text { Not } \\
\text { identifiable in } \\
\text { essay }\end{array}$ & $\begin{array}{l}\text { Did not include related } \\
\text { topics }\end{array}$ & $\begin{array}{l}\text { Mentioned tangential topics } \\
\text { vaguely }\end{array}$ & $\begin{array}{l}\text { Incorporated tangential topics } \\
\text { inappropriately with too much } \\
\text { information given to them }\end{array}$ & $\begin{array}{l}\text { Incorporated tangential } \\
\text { topics as appropriate }\end{array}$ \\
\hline & $\begin{array}{l}\text { Logic / } \\
\text { Significance }\end{array}$ & 4 & 4 & $\begin{array}{l}\text { Not } \\
\text { identifiable in } \\
\text { essay }\end{array}$ & $\begin{array}{l}\text { Mentions only the factor } \\
\text { that fits with the authors } \\
\text { point of view }\end{array}$ & $\begin{array}{l}\text { Discusses a few factors, } \\
\text { but miss some significant } \\
\text { ones }\end{array}$ & $\begin{array}{l}\text { Discusses a plethora of } \\
\text { factors, but are not the main } \\
\text { ones }\end{array}$ & $\begin{array}{l}\text { Discussed the most } \\
\text { significant factors }\end{array}$ \\
\hline & Fairness & 4 & 4 & $\begin{array}{l}\text { Not } \\
\text { identifiable in } \\
\text { essay }\end{array}$ & $\begin{array}{l}\text { Unfairly represents } \\
\text { others viewpoints, }\end{array}$ & $\begin{array}{l}\text { Only considers your own } \\
\text { interest in the matter }\end{array}$ & $\begin{array}{l}\text { Represents the viewpoints of } \\
\text { others, considers your others } \\
\text { interest in the matter }\end{array}$ & $\begin{array}{l}\text { Sympathetically represents } \\
\text { the viewpoints of others, } \\
\text { considers your own an } \\
\text { others interests in the } \\
\text { matter }\end{array}$ \\
\hline
\end{tabular}




\section{Summer 2016- Critical Thinking Rubric based on Skills}

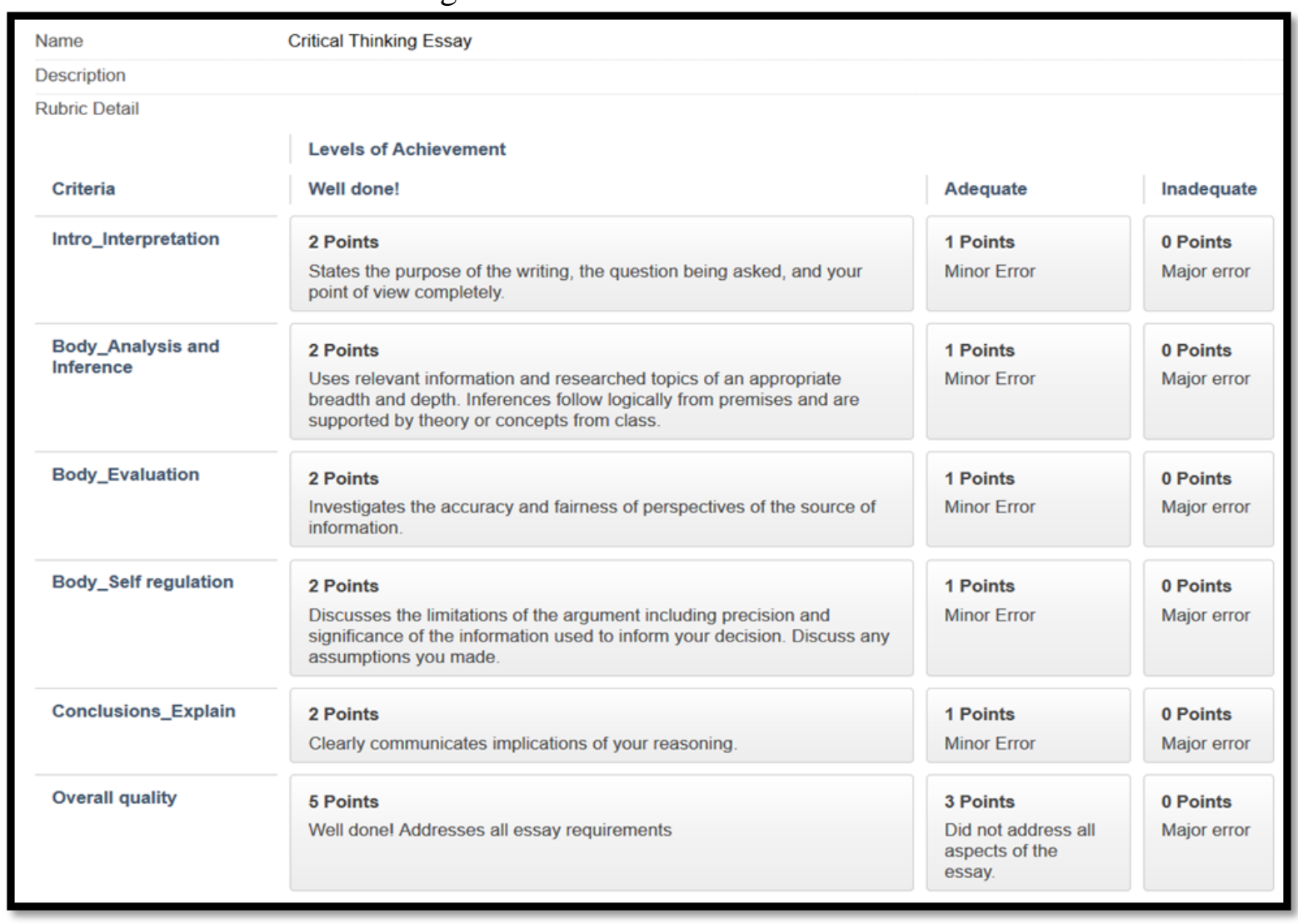

Fall 2016 and Summer 2017- Critical Thinking Rubric based on Skills with GAIN scale

\begin{tabular}{|c|c|c|c|c|c|}
\hline \multicolumn{6}{|l|}{ Critical Thinking Rubric } \\
\hline \multirow{2}{*}{ Criteria } & \multicolumn{4}{|c|}{ Ratings } & \multirow{2}{*}{$\begin{array}{c}\text { Pts } \\
3.0 \text { pts }\end{array}$} \\
\hline & $\begin{array}{l}3.0 \mathrm{pts} \\
\text { Great }\end{array}$ & $\begin{array}{l}2.0 \mathrm{pts} \\
\text { Adequate }\end{array}$ & $\begin{array}{l}1.0 \mathrm{pts} \\
\text { Insufficient }\end{array}$ & $\begin{array}{l}0.0 \mathrm{pts} \\
\text { No } \\
\text { Marks }\end{array}$ & \\
\hline $\begin{array}{l}\text { Analyze the information compared to relevant theory/concepts ensuring accuracy, precision, } \\
\text { and relevance }\end{array}$ & $\begin{array}{l}3.0 \text { pts } \\
\text { Great }\end{array}$ & $\begin{array}{l}2.0 \mathrm{pts} \\
\text { Adequate }\end{array}$ & $\begin{array}{l}1.0 \text { pts } \\
\text { Insufficient }\end{array}$ & $\begin{array}{l}0.0 \text { pts } \\
\text { No } \\
\text { Marks }\end{array}$ & $3.0 \mathrm{pts}$ \\
\hline $\begin{array}{l}\text { Make inferences regarding alternative soluutions: examining the question with enough breath } \\
\text { and depth }\end{array}$ & $\begin{array}{l}3.0 \mathrm{pts} \\
\text { Great }\end{array}$ & $\begin{array}{l}2.0 \mathrm{pts} \\
\text { Adequate }\end{array}$ & $\begin{array}{l}1.0 \mathrm{pts} \\
\text { Insufficient }\end{array}$ & $\begin{array}{l}0.0 \mathrm{pts} \\
\text { No } \\
\text { Marks }\end{array}$ & $3.0 \mathrm{pts}$ \\
\hline $\begin{array}{l}\text { Justify your recommendation: highlight significance of potential implictions and consequences } \\
\text { of inaction }\end{array}$ & $\begin{array}{l}3.0 \mathrm{pts} \\
\text { Grear }\end{array}$ & $\begin{array}{l}2.0 \mathrm{pts} \\
\text { Adequate }\end{array}$ & $\begin{array}{l}1.0 \mathrm{pts} \\
\text { Insufficient }\end{array}$ & $\begin{array}{l}0.0 \mathrm{pts} \\
\text { No } \\
\text { Marks }\end{array}$ & 3.0 pts \\
\hline Evaluate your recommendation: what are the limitations that may bias your judgement & $\begin{array}{l}3.0 \text { pts } \\
\text { Great }\end{array}$ & $\begin{array}{l}2.0 \mathrm{pts} \\
\text { Adequate }\end{array}$ & $\begin{array}{l}1.0 \text { pts } \\
\text { Insufficient }\end{array}$ & $\begin{array}{l}0.0 \mathrm{pts} \\
\text { No } \\
\text { Marks }\end{array}$ & $3.0 \mathrm{pts}$ \\
\hline & & & & Total & ts: 15.0 \\
\hline
\end{tabular}




\section{APPENDIX C: Critical Thinking PROCESS rubric}

\section{Spring 2018}

\begin{tabular}{|c|c|c|c|c|c|}
\hline \multicolumn{5}{|l|}{ Critical Thinking PROCESS rubric. } & ब Qயi \\
\hline Criteria & \multicolumn{4}{|c|}{ Ratings } & Pts \\
\hline $\begin{array}{l}\text { Present the Point (Purpose/Question): } \\
\text { The introduction sets the stage to describe what you will be writing about. Be clear and } \\
\text { precise! (What is the problem and what do you want to do/encourage others to do about } \\
\text { it?) State your stance clearly. }\end{array}$ & $\begin{array}{l}3 \text { pts } \\
\text { Good }\end{array}$ & $\begin{array}{l}2 \mathrm{pts} \\
\text { Adequate }\end{array}$ & $\begin{array}{l}1 \mathrm{pts} \\
\text { Inadequate }\end{array}$ & $\begin{array}{l}0 \text { pts } \\
\text { No } \\
\text { Marks }\end{array}$ & 3 pts \\
\hline $\begin{array}{l}\text { Represent the model (Point of view/Concepts) } \\
\text { In the body of the essay, introduce the framework you use to form your argument. (What } \\
\text { relevant theories/concepts did I use to analyze information?) Ensure the model you } \\
\text { choose is relevant. }\end{array}$ & $\begin{array}{l}3 \text { pts } \\
\text { Good }\end{array}$ & $\begin{array}{l}2 \mathrm{pts} \\
\text { Adequate }\end{array}$ & $\begin{array}{l}1 \mathrm{pts} \\
\text { Inadequate }\end{array}$ & $\begin{array}{l}0 \text { pts } \\
\text { No } \\
\text { Marks }\end{array}$ & 3 pts \\
\hline $\begin{array}{l}\text { Organize evidence (Information) } \\
\text { Next, present information to support your argument and address any evidence against } \\
\text { your argument. (What are the significant facts, costs, benefits?) }\end{array}$ & $\begin{array}{l}3 \text { pts } \\
\text { Good }\end{array}$ & $\begin{array}{l}2 \mathrm{pts} \\
\text { Adequate }\end{array}$ & $\begin{array}{l}1 \mathrm{pts} \\
\text { Inadequate }\end{array}$ & $\begin{array}{l}0 \text { pts } \\
\text { No } \\
\text { Marks }\end{array}$ & 3 pts \\
\hline $\begin{array}{l}\text { Calculations and other Considerations (Interpretation and Inferences) } \\
\text { Examine the topic with enough breadth and depth for a thorough analysis. Inferences } \\
\text { should logically follow from the evidence. (What are you basing your reasoning on?) }\end{array}$ & $\begin{array}{l}3 \text { pts } \\
\text { Good }\end{array}$ & $\begin{array}{l}2 \text { pts } \\
\text { Adequate }\end{array}$ & $\begin{array}{l}1 \mathrm{pts} \\
\text { Inadequate }\end{array}$ & $\begin{array}{l}0 \text { pts } \\
\text { No } \\
\text { Marks }\end{array}$ & 3 pts \\
\hline $\begin{array}{l}\text { Evaluate effect of action/inaction (Implications and Consequences) } \\
\text { Ensure you are using credible information from sources that are reputable and } \\
\text { fairminded. Check that your recommendation will not have adverse outcomes for } \\
\text { stakeholders. (Have you considered all perspectives and how the action would impact } \\
\text { different groups?) }\end{array}$ & $\begin{array}{l}3 \text { pts } \\
\text { Good }\end{array}$ & $\begin{array}{l}2 \mathrm{pts} \\
\text { Adequate }\end{array}$ & $\begin{array}{l}1 \mathrm{pts} \\
\text { Inadequate }\end{array}$ & $\begin{array}{l}0 \text { pts } \\
\text { No } \\
\text { Marks }\end{array}$ & 3 pts \\
\hline $\begin{array}{l}\text { State Recommendation (Revisit the purpose) } \\
\text { In the concluding paragraph, reiterate the point of the writing. Justify your } \\
\text { recommendation. Highlight significance of potential implications and consequences } \\
\text { (What did you attempt to accomplish through this writing?) }\end{array}$ & $\begin{array}{l}3 \text { pts } \\
\text { Good }\end{array}$ & $\begin{array}{l}2 \text { pts } \\
\text { Adequate }\end{array}$ & $\begin{array}{l}1 \mathrm{pts} \\
\text { Inadequate }\end{array}$ & $\begin{array}{l}0 \text { pts } \\
\text { No } \\
\text { Marks }\end{array}$ & 3 pts \\
\hline $\begin{array}{l}\text { Self-Regulation (Assumptions / Limitations) } \\
\text { Ensure your argument meets intellectual standards for critical thinking. Address any } \\
\text { caveats, indicating your confidence or competence in making this claim. (What are the } \\
\text { limitations that may bias your judgment?) }\end{array}$ & $\begin{array}{l}2 \text { pts } \\
\text { Good }\end{array}$ & $\begin{array}{l}1.5 \mathrm{pts} \\
\text { Adequate }\end{array}$ & $\begin{array}{l}1 \mathrm{pts} \\
\text { Inadequate }\end{array}$ & $\begin{array}{l}0 \text { pts } \\
\text { No } \\
\text { Marks }\end{array}$ & 2 pts \\
\hline & & & & Total & ts: 20 \\
\hline
\end{tabular}

